\section{Fruit Yield, Size, and Color Responses of Two Greenhouse Cucumber Types to Nitrogen Fertilization in Perlite Soilless Culture}

\author{
C. Jasso-Chaverria ${ }^{1}$, G.J. Hochmuth ${ }^{1}$, R.C. Hochmuth ${ }^{1}$, and \\ S.A. Sargent ${ }^{2}$
}

AdDitional INDEX wORDs. hydroponics, fertilization, fruit color, fruit quality, Cucumis sativus $\mathrm{L}$., seedless cucumber

Summary. Two greenhouse cucumber (Cucumis sativus) cultivars with differing fruit types [European ('Bologna') and Beit-alpha ('Sarig')] were grown during two seasons in a perlite medium in black plastic nursery containers in a passively ventilated greenhouse in northern Florida to evaluate fruiting responses to nitrogen $(\mathrm{N})$ fertilization over the range of 75 to $375 \mathrm{mg} \cdot \mathrm{L}^{-1}$. Fruit production, consisting mostly of fancy fruits, increased quadratically with $\mathrm{N}$ concentration in the nutrient solution, leveling off above $225 \mathrm{mg} \cdot \mathrm{L}^{-1}$ for both cucumber cultivars. Fruit length and diameter were not affected by $\mathrm{N}$ concentration in the nutrient solution. Leaf $\mathrm{N}$ concentration, averaged over three sampling dates, increased linearly with $\mathrm{N}$ concentration in the nutrient solution from $46 \mathrm{~g} \cdot \mathrm{kg}^{-1}$ with 75 $\mathrm{mg} \cdot \mathrm{L}^{-1} \mathrm{~N}$ to $50 \mathrm{~g} \cdot \mathrm{kg}^{-1}$ with $375 \mathrm{mg} \cdot \mathrm{L}^{-1} \mathrm{~N}$. Fruit firmness decreased with increasing $\mathbf{N}$ concentration and there was little difference in firmness between the two cultivars. Firmness was similar across three measurement dates during the spring harvest season, but increased during the season in the fall. Fruit color responses to $\mathrm{N}$ concentration were dependent on the specific combination of experiment, sampling date, and cultivar. For most combinations of experiment, sampling date, and cultivar, cucumber epidermal color was greener (higher hue angle) with increased $\mathrm{N}$ concentration. The color was darkest (lowest $\mathrm{L}^{*}$ value) and most intense (highest chroma value) with intermediate to higher $\mathrm{N}$ concentrations.

$\longrightarrow$ ucumber is one of the most important vegetables grown in greenhouses around the world, including Florida (Hochmuth and Hochmuth, 1991; Tyson et al., 2001). Greenhouse cucumbers are grown in many soil-based and soilless cultural systems, depending on the production area, the relative threat of soilborne diseases, and the availability of soilless media. In Florida, most greenhouse vegetables are produced in perlite medium with nutrients and water delivered regularly by microirrigation (Hochmuth and Hochmuth, 2001, 2003; Sweat and Hochmuth, 2001). Current University of Florida recommendation for $\mathrm{N}$ for cucumber is $240 \mathrm{mg} \cdot \mathrm{L}^{-1}$ in the nutrient solution during the fruiting season $(\mathrm{G}$. Hochmuth, 2001; R. Hochmuth,

${ }^{1}$ North Florida Research and Education Center-Suwannee Valley, University of Florida, Live Oak, FL

${ }^{2}$ Horticultural Sciences Department, University of Florida, Gainesville, FL

Florida Agricultural Experiment Station Journal Series No. R-09971
2001). Nutrient sources are similar to those used for tomato (Hochmuth and Hochmuth, 2001). Research has been conducted on $\mathrm{N}$ fertilization of greenhouse cucumbers, but most work has been done with Europeantype cucumbers, in areas other than the U.S., or with media systems other than perlite. No research reports could be found dealing with perlite medium with Beit-alpha (mini) cucumbers. rockwool medium, found that yield of European-type greenhouse cucumbers increased with $\mathrm{N}$ concentration to 225 Researchers in Florida, working with $\mathrm{mg} \cdot \mathrm{L}^{-1}$ (Schon and Compton, 1997a). The recommendation for greenhouse vegetable producers using soilless cultural systems is to allow for a fraction of the nutrient solution to leach from the medium, after each irrigation, to minimize soluble salt build-up in the medium (G. Hochmuth, 2001). The duration of $\mathrm{N}$ depletion from the medium decreased as the $\mathrm{N}$ concentration in the nutrient solution increased (Schon and Compton, 1997b), pointing to the need to manage $\mathrm{N}$ and leaching fraction together to minimize $\mathrm{N}$ losses from the medium, which could lead to $\mathrm{N}$ contamination of the ground beneath or around the greenhouse. With tomato (Lycopersicon esculentum) growing in containers of soil, intermediate concentrations of $\mathrm{N}\left(175 \mathrm{mg} \cdot \mathrm{L}^{-1}\right)$ with the irrigation water led to maximum yield and minimum losses of $\mathrm{N}$ from the soil (Papadopoulos, 1987).

Vegetable fruit quality is often related to $\mathrm{N}$ fertilization (Locascio et al., 1984; Mozafar, 1993). Research into optimum $\mathrm{N}$ fertilization should include evaluations of fruit quality in addition to yield measurements. Excessive rates of $\mathrm{N}$ reduced fruit firmness, soluble solids, and flavor in a field study with strawberry (Fragaria ananassa) (Sistrunk and Morris, 1985). In another study with strawberry, fruit firmness decreased with increasing $\mathrm{N}$ fertilization (Miner et al., 1997).

In a study with cucumber in Spain in a loamy sand soil in a greenhouse, fruit quality and yield were reduced with excessive $\mathrm{N}$ fertilization (Ruiz and Romero, 1998). In a soil-based system, $\mathrm{N}$ rates greater than $50 \mathrm{~kg} \cdot \mathrm{ha}^{-1}$ were excessive for cucumber (Castilla et al., 1991).

The objectives of our studies were to determine the $\mathrm{N}$ requirements of greenhouse cucumber growing in perlite under Florida conditions and to determine if the $\mathrm{N}$ requirements differed for two different fruiting types

\begin{tabular}{llll}
\hline $\begin{array}{l}\text { Units } \\
\begin{array}{l}\text { To convert U.S. to SI, } \\
\text { multiply by }\end{array}\end{array}$ & U.S. unit & SI unit & $\begin{array}{l}\text { To convert SI to U.S., } \\
\text { multiply by }\end{array}$ \\
\hline 10 & $\%$ & $\mathrm{~g} \cdot \mathrm{kg}^{-1}$ & 0.1 \\
0.3048 & $\mathrm{ft}$ & $\mathrm{m}$ & 3.2808 \\
3.7854 & $\mathrm{gal}$ & $\mathrm{L}$ & 0.2642 \\
2.5400 & inch $(\mathrm{es})$ & $\mathrm{cm}$ & 0.3937 \\
0.4536 & $\mathrm{lb}$ & $\mathrm{kg}$ & 2.2046 \\
1.1209 & $\mathrm{lb} / \mathrm{acre}$ & $\mathrm{kg} \cdot \mathrm{ha}^{-1}$ & 0.8922 \\
4.4482 & $\mathrm{lbf}$ & $\mathrm{N}$ & 0.2248 \\
1 & $\mathrm{ppm}$ & $\mathrm{mg} \cdot \mathrm{kg}^{-1}$ & 1 \\
1 & $\mathrm{ppm}$ & $\mathrm{mg} \cdot \mathrm{L}^{-1}$ & 1 \\
$\left({ }^{\circ} \mathrm{F}-32\right) \div 1.8$ & ${ }^{\circ} \mathrm{F}$ & ${ }^{\circ} \mathrm{C}$ & $\left(1.8 \times{ }^{\circ} \mathrm{C}\right)+32$
\end{tabular}




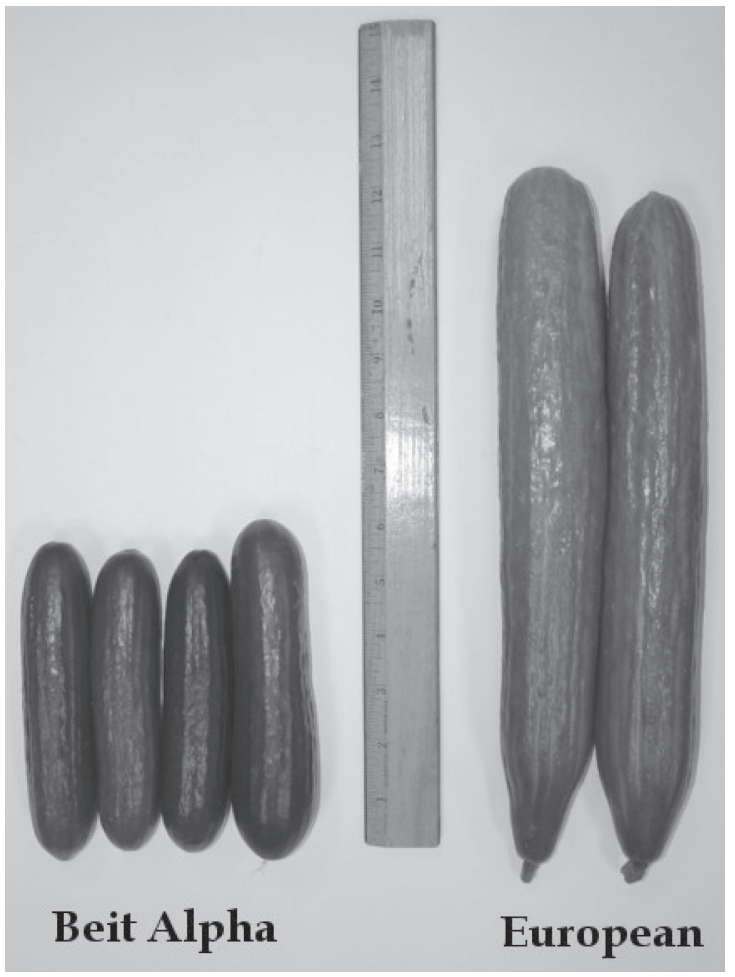

Fig. 1. The two cucumber fruiting types used in study, Beit-alpha ('Sarig') and European ('Bologna').

of cucumber. Since green color is an important quality attribute for cucumber, we also evaluated effects of $\mathrm{N}$ fertilization on color attributes (greenness, color darkness, and perceived color intensity). There are no benchmark values for these quality attributes for greenhouse cucumbers.

\section{Materials and methods}

Two greenhouse, seedless cucumber types were grown in a passively ventilated greenhouse in northern Florida to evaluate $\mathrm{N}$ fertilization needs for optimal fruit production and quality. Two types of cucumbers (Fig. 1) were used, a European longfruit type, 'Bologna' (Hazera Seeds, El Segundo, Calif.), and a short-fruited "Beit-alpha" (mini cucumber) type, 'Sarig' (Rijk Zwaan USA, Salinas, Calif.). The study was conducted in the spring and fall seasons of 2001 at the University of Florida's North Florida Research and Education Center-Suwannee Valley, near Live Oak in north central Florida. The greenhouse was a double-poly (inflated) covered greenhouse with side-wall ventilation screens with a curtain cover, and a ridge vent (Atlas Greenhouse Co., Alapaha, Ga.). The stand-alone greenhouse structure was $30.0 \times 60.0 \mathrm{ft}$ in size with $8.0-\mathrm{ft}$ side-walls. The greenhouse environment was managed to maintain air temperatures no higher than 85 ${ }^{\circ} \mathrm{F}$ in the day by opening or closing the roof vent and sidewall curtains. Heat was provided at night from liquid propane furnaces when required from late fall through early spring to maintain night temperature at or above $65^{\circ} \mathrm{F}$.

Cucumber seeds were sown in a peat-mix medium (Metro-mix 220, Scotts Co., Marysville, Ohio) in styrofoam seedling trays with cell size of $1.0 \times 1.0$ inch and 3.0 inches deep (Speedling Inc., Sun City, Fla.). The seeds were sown on 19 Feb. and 15 Aug. 2001 for the spring and fall trials, respectively. After seedling emergence, the plants were irrigated every second day with a nutrient solution (G. Hochmuth, 2001 ) with the following nutrients and concentration $\left(\mathrm{mg} \cdot \mathrm{L}^{-1}\right)$ : $75 \mathrm{~N}$ (nitrate form), 60 phosphorus, 150 potassium, 100 calcium, 50 magnesium, 70 sulfur, 2.5 iron, 0.4 boron, 0.05 copper, 0.6 manganese, 0.03 molybdenum, and 0.1 zinc. The irrigation water supplied an additional $100 \mathrm{mg} \cdot \mathrm{L}^{-1}$ calcium. After $12 \mathrm{~d}$ of seedling growth, plants were removed from the seedling trays and planted into perlite media in 3.0-gal black plastic nursery containers with one cucumber plant per container. The perlite was fine-grade perlite (Airlite Corp., Vero Beach, Fla.). Plants were immediately irrigated with the seedling nutrient solution and the containers were placed on 12.0-inch-wide styrofoam boards (for cold-floor temperature insulation) on the greenhouse floor which was covered with black nursery cloth. The plants were irrigated with nutrient solution in each irrigation event, delivered through $2.0-\mathrm{L} \cdot \mathrm{h}^{-1}$ microjet emitters (Netafim, Altamonte Springs, Fla.). The frequency and duration of irrigation events were determined by measuring leachate from the nursery containers and adjusting the irrigation frequency and/or volume to meet a $20 \%$ leachate level (Schon and Compton, 1997b). The leachate level of $20 \%$ was set for the treatment receiving 150 $\mathrm{mg} \cdot \mathrm{L}^{-1} \mathrm{~N}$ to be an average leachate for all cucumbers in the experiment. At this level of leaching, all plants received adequate (no wilting observed) irrigation, ranging from twice daily (for 3 min each) early in the growth season to 10 times daily (for $10 \mathrm{~min}$ each) during the harvesting season.

The $\mathrm{N}$ concentration treatments were $75,150,225,300$, and 375 $\mathrm{mg} \cdot \mathrm{L}^{-1}$ made by adjusting the amount of calcium nitrate in the nutrient solution. Although Ca concentration varied with the $\mathrm{N}$ treatment, total $\mathrm{Ca}$ was adequate with all $\mathrm{N}$ treatments, because an additional $100 \mathrm{mg} \cdot \mathrm{L}^{-1}$ was supplied from the native Ca in the well water. No Ca deficiency was observed during the course of the experiments, and leaf-Ca concentrations were always sufficient. The other nutrients in the solution were supplied as described above for the seedling-stage solution. The five nutrient solution treatments were injected into the irrigation delivery system by peristaltic pumps (model 7553-80 with Easy-Load Masterflex model 7580-10 heads; Cole-Parmer Instrument Co., Vernon Hills, Ill.) to the respective plants. Each $\mathrm{N}$ treatment was delivered through a separate irrigation system. The pumps were operated by an irrigation controller (model Sterling 8; Superior Controls Co., Valencia, Calif.). The uniformity of the irrigation system was determined at the beginning of the experiment to be $95 \%$ (Smajstrla et al., 1988).

The experiment was a factorial experiment in a randomized, completeblock design with cucumber cultivars, N treatments, and seasons as the factors with four replicates of the treatment combinations. For some variables (e.g., leaf- $\mathrm{N}$ concentration and fruit quality measurements) there was a sampling date factor added to the analysis model. There were five cucumber plants (each plant in a single pot) comprising an experimental unit. Seedlings were placed in two double-rows in the greenhouse and plants in each row were trained on polypropylene twine attached to a wire cable $8.0 \mathrm{ft}$ above the floor. Upon reaching the trellis cable, the plants were draped over the cable and allowed to grow toward the floor (Hochmuth et al., 1996). The experiment was terminated once the growing tips reached the floor of the greenhouse.

During the growth period, all axillary vegetative buds were removed 
from the main stem, and periodically the stem was attached to the twine with plastic plant clips. Flower buds were removed from the lowest five nodes of the plant at the start of the growth cycle. After the fifth node, fruit clusters at each node were thinned to one fruit at the time flowers began to open at the node.

During the growing season, insects and diseases were controlled with recommended labeled pesticides, when needed. The main insect pest was the silverleaf whitefly (Bemisia argentifolia) and the main disease problem was powdery mildew (Erysiphe cichoracearum). Plant growth was normal for these cucumber crops and no production problems were encountered.

Samples of most-recently-matured whole leaves were collected three times during the seasons for mineral nutrient determinations. The samples were taken at the eight-node stage, the first-harvest stage, and the 10th-harvest stage. These stages were about 40,50 , and $75 \mathrm{~d}$, respectively, after seed sowing. Leaves were dried in a forced-air oven and sent to a commercial analytical lab for nutrient determinations with $\mathrm{N}$ by Kjeldahl, $\mathrm{S}$ by combustion and sulfur analyzer, and the other elements by plasma-emission spectroscopy. Fruits were harvested three times each week from 10 Apr. until 30 May for the spring crop, and from 26 Sept. to 26 Oct. for the fall crop. Fruits were graded according to USDA standards (USDA, 1997) and measurements were made of fruit diameter and length. Fruit quality evaluations were conducted three times in each season (third, tenth, and fifteenth harvest dates). Fruit epidermal color was determined by reflectance (Chromo-meter 200, model 3.0; Minolta Co., Osaka, Japan) in CIE scale (Francis, 1980) from $L^{*}, a^{*}$, and $b^{*}$ values. These $a^{*}$ and $b^{*}$ values were used to calculate hue angle and chroma value (Francis, 1970, 1980). Firmness was determined as bio-yield point using an Instron Universal Testing Instrument (Instron IX Automated Material Testing System; Instron Corp., Atlanta, Ga). The bioyield point was the maximum force obtained by a convex tip, 0.43 inch in diameter moving at a cross-head speed of 3.9 inches/min applied to the fruit pulp at the equator (epidermis removed). The bio-yield point was expressed in Newtons. Measurements on three fruits from each experimental unit were averaged.

All data were analyzed by SAS procedures (SAS Institute, 1995), using season, cultivar, and $\mathrm{N}$ concentration as factors. Sampling date was an additional factor involved in the analyses on fruit quality and leaf nutrient concentration data. Main effects and interactions were evaluated, when significant, with Fishers protected least significant difference $\left(\mathrm{LSD}_{0.05}\right)$, and responses to $\mathrm{N}$ treatment, when significant, were evaluated with regression analysis.

\section{Results and discussion}

Early (first five harvests) and total-season fruit length and diameter were influenced by the interaction of season and cultivar (Fig. 2). Fruit length and diameter, as expected, were greater for the European cucumber compared to the Beit-alpha cucumber, and the differences in length and diameter were greater for the spring trial than with the fall trial. Numbers of fruits per plant were greater for the Beit-alpha type 'Sarig' than for the European type 'Bologna' in both trials, but the difference was greater in the spring trial than the fall trial. Early marketable fruit production (first five harvests) was $0.7 \mathrm{~kg} /$ plant for the spring trial and $0.5 \mathrm{~kg} /$ plant for the fall trial (data not shown). All marketable fruit production consisted of fancy-grade fruits. There were no cull fruits in the early harvests. The
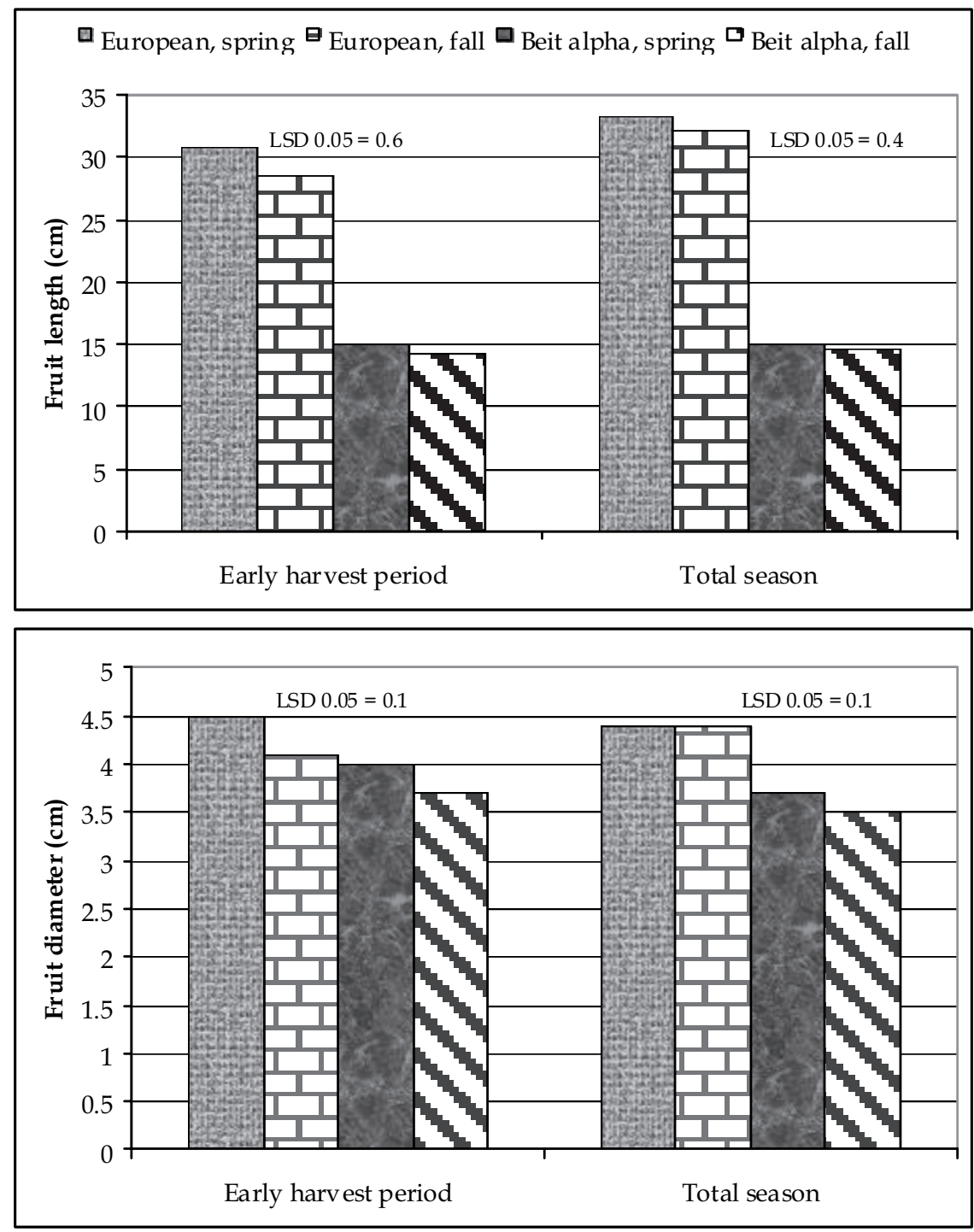

Fig. 2. Effects of interaction of season and cucumber type on fruit length and diameter for early (first five harvests) and total-season harvest periods of cucumbers grown in perlite media $\left(1 \mathrm{~cm}=0.3937 \mathrm{inch} ; \mathrm{LSD}_{0.05}=\right.$ least significant difference at $P=0.05)$. 
European cucumber produced 0.7 $\mathrm{kg}$ early marketable fruits/plant while the Beit-alpha cucumber produced 0.4 $\mathrm{kg} /$ plant (data not shown). Early fruit production responded to $\mathrm{N}$ concentration in the nutrient solution (Table 1 ). Numbers of fruits per plant and early marketable and fancy fruit production increased linearly with $\mathrm{N}$ concentration over the range of 75 to $375 \mathrm{mg} \cdot \mathrm{L}^{-1} \mathrm{~N}$. Fruit length and diameter were not affected by $\mathrm{N}$ concentration in the irrigation solution.

The interaction of season and cultivar was significant for total-season fruit length and diameter (Fig. $2)$. Fruits were shorter in the fall than spring, especially for the longer-fruited European cucumber. Fall-grown fruits of the shorter Beit-alpha type were also smaller in diameter than those grown in the spring, but differences were not significant for the longer-fruited European cucumber type.

Total-season numbers of fruits per plant and average seasonal fruit length and diameter were not affected by $\mathrm{N}$ concentration (Table 2). Quantities of fancy and total marketable fruits per plant responded quadratically to $\mathrm{N}$ concentration (Table 2). The regression functions were maximized with 230 and $250 \mathrm{mg} \cdot \mathrm{L}^{-1} \mathrm{~N}$, respectively, in the irrigation solution. Schon and Compton (1997a) observed similar responses of cucumber yield to $\mathrm{N}$ concentration. Yields of No. 1 and cull fruits were reduced linearly as $\mathrm{N}$ rate increased.

Leaf $\mathrm{N}$ concentration was affected by the interaction of season, sampling date, and cucumber type (Fig. 3). Leaf$\mathrm{N}$ concentration with the European cucumber increased over the spring season but leaf- $\mathrm{N}$ concentration with the Beit-alpha cucumber fell off on the third sampling date. In the fall season, leaf-N concentration with both cucumber types followed a similar pattern across sampling dates with the leaf- $\mathrm{N}$ concentration lowest at the second sampling period. Leaf- $\mathrm{N}$ concentration increased linearly $(\% \mathrm{~N}=45+0.014 \mathrm{~N}$, where $\mathrm{N}$ is solution $\mathrm{N}$ concentration in milligrams per liter). These leaf- $\mathrm{N}$ responses are consistent with leaf-N sufficiency ranges of Jones (1983) and Jones et al. (1991). Leaf-N values near $46 \mathrm{~g} \cdot \mathrm{kg}^{-1}$ are considered to be on the deficient side of the sufficiency range (Jones et al., 1991). All other leaf nutrient concentrations were in the sufficiency ranges (G. Hochmuth, 2001;

Table 1. Early (first five harvests) cucumber fruit size and yield responses to nutrient solution nitrogen $(\mathrm{N})$ concentration.

\begin{tabular}{lrrrrrr}
\hline & \multicolumn{5}{c}{ Solution $\mathbf{N}$ concn $\left[\mathbf{m g} \cdot \mathrm{L}^{-1}(\mathbf{p p m})\right]$} \\
\cline { 2 - 7 } Variable $^{\mathrm{z}}$ & $\mathbf{7 5}$ & $\mathbf{1 5 0}$ & $\mathbf{2 2 5}$ & $\mathbf{3 0 0}$ & $\mathbf{3 7 5}$ & Model $^{\mathrm{y}} \mathbf{Y}=$ \\
\hline No. of fruits per plant & 2.2 & 2.5 & 2.6 & 2.6 & 2.9 & $2.1+0.001 \mathrm{~N}$ \\
Fruit length $(\mathrm{cm})$ & 22.3 & 21.5 & 22.1 & 22.3 & 22.5 & $\mathrm{NS}$ \\
Fruit diam $(\mathrm{cm})$ & 4.0 & 4.0 & 4.1 & 4.1 & 4.1 & $\mathrm{NS}$ \\
Marketable fruits per plant $(\mathrm{kg})$ & 0.5 & 0.5 & 0.6 & 0.6 & 0.7 & $0.6+0.0008 \mathrm{~N}$ \\
Fancy fruits per plant $(\mathrm{kg})$ & 0.4 & 0.5 & 0.6 & 0.6 & 0.7 & $0.5+0.001 \mathrm{~N}$ \\
\hline
\end{tabular}

${ }^{2} 1 \mathrm{~cm}=0.3937$ inch; $1.0 \mathrm{~kg}=2.2046 \mathrm{lb}$

${ }^{y} \mathrm{~N}$ is solution nitrogen concentration in $\mathrm{mg} \cdot \mathrm{L}^{-1}$.

"Nonsignificant.

Table 2. Total-season cucumber fruit size and yield responses to nutrient solution nitrogen $(\mathrm{N})$ concentration.

\begin{tabular}{|c|c|c|c|c|c|c|}
\hline \multirow[b]{2}{*}{ Variable $^{\mathrm{z}}$} & \multicolumn{6}{|c|}{ Solution $\mathrm{N}$ concn $\left[\mathrm{mg} \cdot \mathrm{L}^{-1}(\mathrm{ppm})\right]$} \\
\hline & 75 & 150 & 225 & 300 & 375 & Model $^{\mathrm{y}} \mathbf{Y}=$ \\
\hline No. of fruits per plant & 22.5 & 25.7 & 25.5 & 24.0 & 22.5 & NS \\
\hline Fruit length $(\mathrm{cm})$ & 23.6 & 23.8 & 23.8 & 23.6 & 24.2 & NS \\
\hline Fruit diam $(\mathrm{cm})$ & 4.0 & 4.0 & 4.0 & 4.0 & 4.0 & NS \\
\hline Marketable fruits per plant $(\mathrm{kg})$ & 4.1 & 4.8 & 4.7 & 4.5 & 4.3 & $\begin{array}{l}3.57+0.01 \mathrm{~N} \\
-0.00002 \mathrm{~N}^{2}\end{array}$ \\
\hline Fancy fruits per plant $(\mathrm{kg})$ & 3.2 & 4.1 & 4.1 & 4.0 & 3.8 & $\begin{array}{r}2.43+0.014 \mathrm{~N} \\
-0.00003 \mathrm{~N}^{2}\end{array}$ \\
\hline No.l fruits per plant $(\mathrm{kg})$ & 0.9 & 0.7 & 0.6 & 0.5 & 0.5 & $0.97-0.0014 \mathrm{~N}$ \\
\hline Cull fruits per plant $(\mathrm{kg})$ & 0.2 & 0.1 & 0.1 & 0.1 & 0.1 & $0.2-0.0003 \mathrm{~N}$ \\
\hline
\end{tabular}

${ }^{2} 1 \mathrm{~cm}=0.3937$ inch; $1.0 \mathrm{~kg}=2.2046 \mathrm{lb}$

${ }^{\mathrm{N}} \mathrm{N}$ is solution nitrogen concentration in $\mathrm{mg} \cdot \mathrm{L}^{-1}$.

ss Nonsignificant.

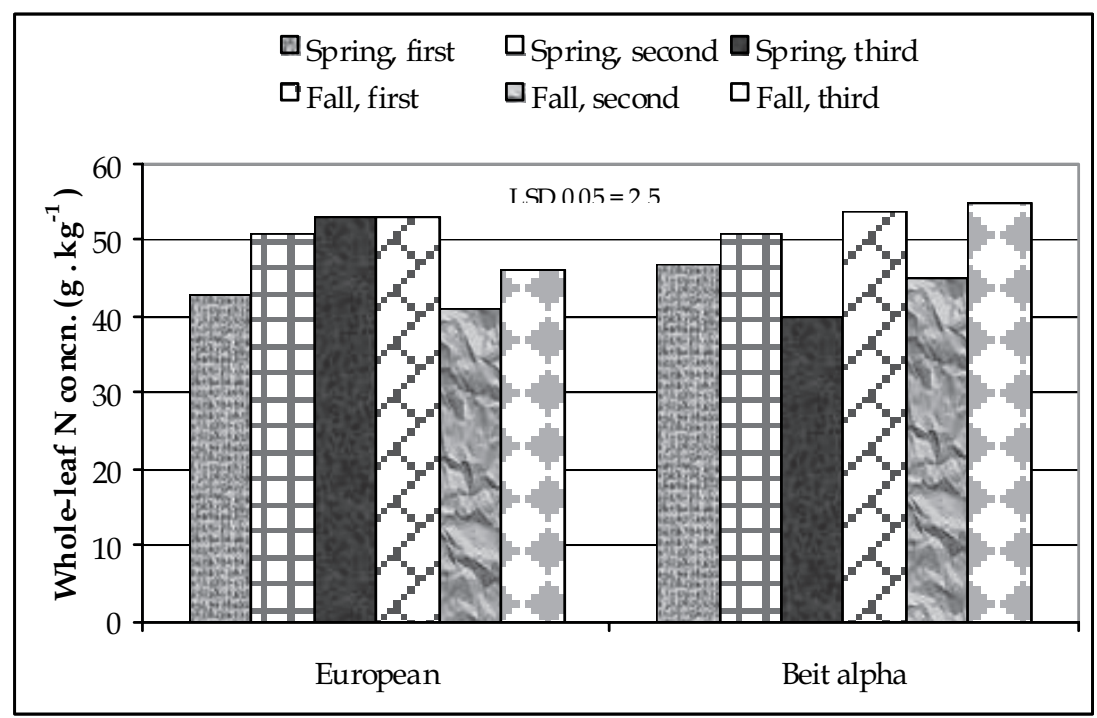

Fig. 3. Effect of interaction of season, sampling period, and cucumber type on whole-leaf nitrogen concentration of cucumbers grown in perlite medium ( 1 $\mathrm{g} \cdot \mathrm{kg}^{-1}=0.1 \% ; \mathrm{LSD}_{0.05}=$ least significant difference at $\left.P=0.05\right)$.

Jones et al., 1991). Leaf macronutrient concentrations $\left(\mathrm{g} \cdot \mathrm{kg}^{-1}\right)$ were $\mathrm{S}=5.8$, $\mathrm{P}=6.8, \mathrm{~K}=38, \mathrm{Mg}=5.6, \mathrm{Ca}=23$, and the micronutrient concentrations $\left(\mathrm{mg} \cdot \mathrm{kg}^{-1}\right)$ were $\mathrm{Fe}=131, \mathrm{Mn}=69, \mathrm{~B}$ $=46, \mathrm{Cu}=9$, and $\mathrm{Zn}=60$.

The Beit-alpha fruits were only slightly firmer at $10.8 \mathrm{~N}$ than the
European cucumber fruits at $10.3 \mathrm{~N}$. These values are similar to results with another Beit-alpha cucumber cultivar grown under similar conditions in another study (Villalta et al., 2003). There was a significant interaction of season and sampling date on fruit firmness (Fig. 4). Firmness was similar 
across sampling dates in spring, but was higher at the second and third sampling dates than the first date in the fall. There were no significant interactions involving solution $\mathrm{N}$ concentration. Fruit firmness decreased as solution $\mathrm{N}$ concentration increased (the model was $\mathrm{F}_{\mathrm{N}}=10.9-0.0014 \mathrm{~N}$, where $\mathrm{F}_{\mathrm{N}}$ is fruit firmness in Newtons and $\mathrm{N}$ is solution $\mathrm{N}$ concentration in parts per million). This observation is similar to results with strawberry (Miner et al., 1997; Sistrunk and Morris, 1985), where fruit firmness was decreased with increased $\mathrm{N}$ fertilization.

The four-way interaction of season, sampling date, cultivar, and $\mathrm{N}$ concentration affected fruit epidermal color reported as hue angle where $90^{\circ}$ $=$ yellow and $180^{\circ}=$ green $($ Table 3$)$. Effects of solution $\mathrm{N}$ concentration on greenness of fruits were variable and more pronounced in the later sampling dates for both seasons. In the spring season, greenness of the European-type fruits was not affected by $\mathrm{N}$ concentration in the first two sampling dates (hue angle about $130^{\circ}$ ), but it increased linearly with $\mathrm{N}$ concentration at the third sampling date, ranging from $127^{\circ}$ to $130^{\circ}$. Greenness of the Beit-alpha fruits increased linearly with solution $\mathrm{N}$ concentration at the first two sampling dates and quadratically for the last sampling date in the spring season. In the fall season, greenness of the European cultivar was not affected by $\mathrm{N}$ concentration at the first sampling date. However, the European-type fruits were greener with the lowest and highest $\mathrm{N}$ concentrations at the second and third sampling dates. Greenness of the Beit-alpha cultivar was not affected by $\mathrm{N}$ concentration on the first sampling date. On the second sampling date, the Beit-alpha cultivar became greener as $\mathrm{N}$ concentration increased, but became less green as $\mathrm{N}$ concentration increased on the third date. Cucumbers in the spring season were slightly greener (hue angle ranging from $127^{\circ}$ to $131^{\circ}$ ) than those grown in the fall season (hue angle ranging from $121^{\circ}$ to $128^{\circ}$ ). All fruits in this study had hue angle measurements associated with marketable fruits.

Lower $\mathrm{L}^{*}$ values are related to increased darkness of color where 0 $=$ black and $100=$ white. Fruits were darker (lower $\mathrm{L}^{*}$ values) with the later sampling dates in the spring but were of similar darkness across fall sampling dates (Fig. 5 ). Fruit color of the Euro-

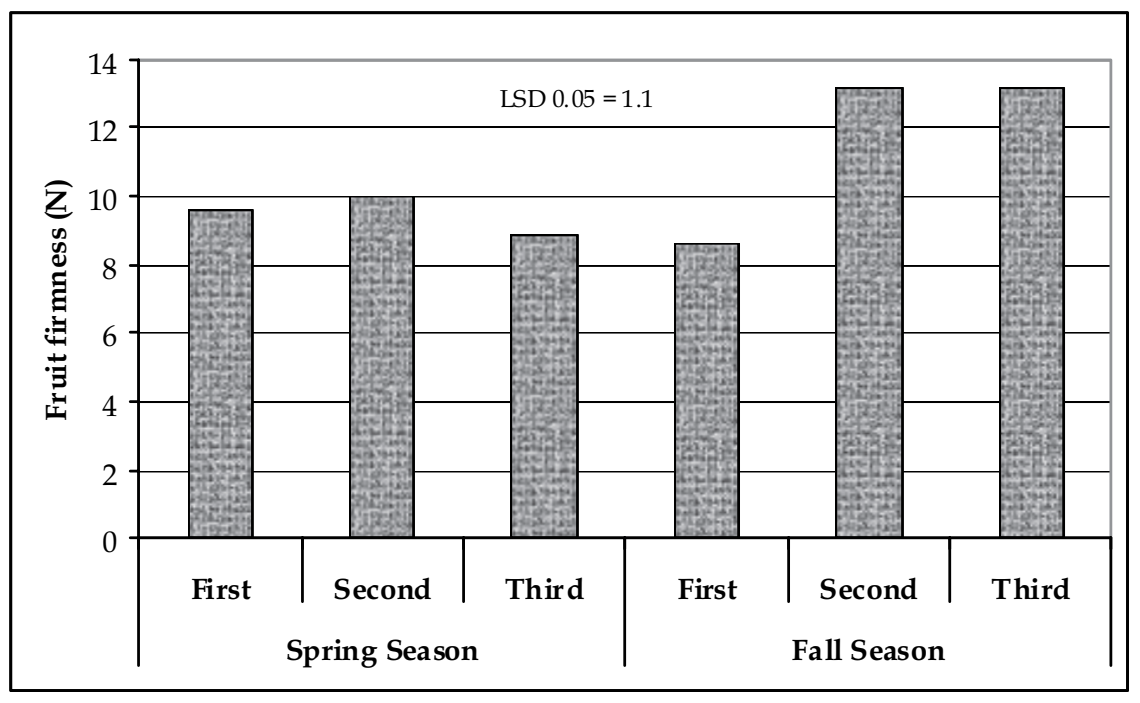

Fig. 4. Effects of interaction of season and sampling period on firmness of cucumber fruits grown in perlite medium. Sampling periods were third, 10th, and 15th harvests $\left(1 \mathrm{~N}=0.2248 \mathrm{lbf} ; \mathrm{LSD}_{0.05}=\right.$ least significant difference at $\left.P=0.05\right)$.

Table 3. Effects of the four-way interaction of season, sampling date, cucumber type, and nitrogen $(\mathrm{N})$ concentration on cucumber external greenness (hue angle).

\begin{tabular}{|c|c|c|c|c|c|c|c|c|c|}
\hline \multirow[b]{2}{*}{ Season } & \multirow{2}{*}{$\begin{array}{c}\text { Sampling } \\
\text { date }^{\mathrm{y}}\end{array}$} & \multirow{2}{*}{$\begin{array}{c}\text { Cucumber } \\
\text { type }\end{array}$} & \multicolumn{5}{|c|}{$\begin{array}{c}\text { Hue angle }\left({ }^{\circ}\right)^{\mathrm{z}} \\
\text { Solution } \mathrm{N} \text { concn } \\
{\left[\mathrm{mg} \cdot \mathrm{L}^{-1}(\mathrm{ppm})\right]}\end{array}$} & \multicolumn{2}{|c|}{ Model } \\
\hline & & & 75 & 150 & 225 & 300 & 375 & $\mathrm{~L}$ & $\mathbf{Q}$ \\
\hline \multirow[t]{6}{*}{ Spring } & \multirow[t]{2}{*}{ First } & European & 131 & 130 & 130 & 130 & 131 & NS & NS \\
\hline & & Beit-alpha & 129 & 128 & 131 & 130 & 130 & * & NS \\
\hline & \multirow{2}{*}{ Second } & European & 128 & 128 & 129 & 130 & 130 & NS & NS \\
\hline & & Beit-alpha & 127 & 128 & 129 & 130 & 130 & * & NS \\
\hline & \multirow[t]{2}{*}{ Third } & European & 128 & 127 & 130 & 129 & 128 & ** & NS \\
\hline & & Beit-alpha & 127 & 125 & 126 & 127 & 129 & ** & ** \\
\hline \multirow[t]{6}{*}{ Fall } & \multirow[t]{2}{*}{ First } & European & 127 & 128 & 128 & 126 & 127 & NS & NS \\
\hline & & Beit-alpha & 124 & 126 & 126 & 125 & 126 & NS & NS \\
\hline & \multirow[t]{2}{*}{ Second } & European & 126 & 126 & 125 & 127 & 126 & NS & * \\
\hline & & Beit-alpha & 124 & 123 & 123 & 124 & 126 & $*$ & NS \\
\hline & \multirow[t]{2}{*}{ Third } & European & 124 & 125 & 121 & 121 & 125 & ** & ** \\
\hline & & Beit-alpha & 124 & 124 & 124 & 122 & 123 & $*$ & NS \\
\hline
\end{tabular}

${ }^{z}$ Higher hue values are associated with greener color, where $90^{\circ}=$ yellow and $180^{\circ}=$ green . 'Sampling dates were third, 10th, and 15 th harvests.

Ns, ${ }^{*},{ }^{*}$ Nonsignificant or significant at $P \leq 0.05$ or 0.01 , respectively; linear $(\mathrm{L})$ and quadratic $(\mathrm{Q})$.

pean cultivar was darker with later than with earlier sampling dates, and for the Beit-alpha type fruits were darkest with the second sampling date. Overall, the European fruits were slightly darker than the Beit-alpha fruits.

$\mathrm{L}^{*}$ value for the European cucumber was not affected by $\mathrm{N}$ concentration in the spring but responded quadratically in the fall (Table 4). Fruits were darker (lower $\mathrm{L}^{\star}$ values) in color with intermediate $\mathrm{N}$ concentrations. Beitalpha fruits responded quadratically to $\mathrm{N}$ concentration in the spring, with darker fruits with intermediate $\mathrm{N}$ concentrations; Darkness decreased with $\mathrm{N}$ concentration in the fall. All fruits in this study ( $\mathrm{L}^{*}$ values 31 to 37 ) were considered marketable.

Chroma values represent perceived color intensity-the higher the value, the more intense the perceived color. Color was slightly more intense at the later sampling dates in spring but it was not affected by sampling date in the fall (Fig. 5). Perceived color intensity was not affected by sampling date with the European cultivar, but was greater with the third sampling date for the Beit-alpha cucumber. Chroma value decreased linearly with $\mathrm{N}$ concentration in the nutrient solution for both cucumber cultivars in the spring season (Table 5). This means perceived color 


$$
\mathbf{Q}_{\text {Spring }} \mathbf{D}_{\text {Fall }}
$$
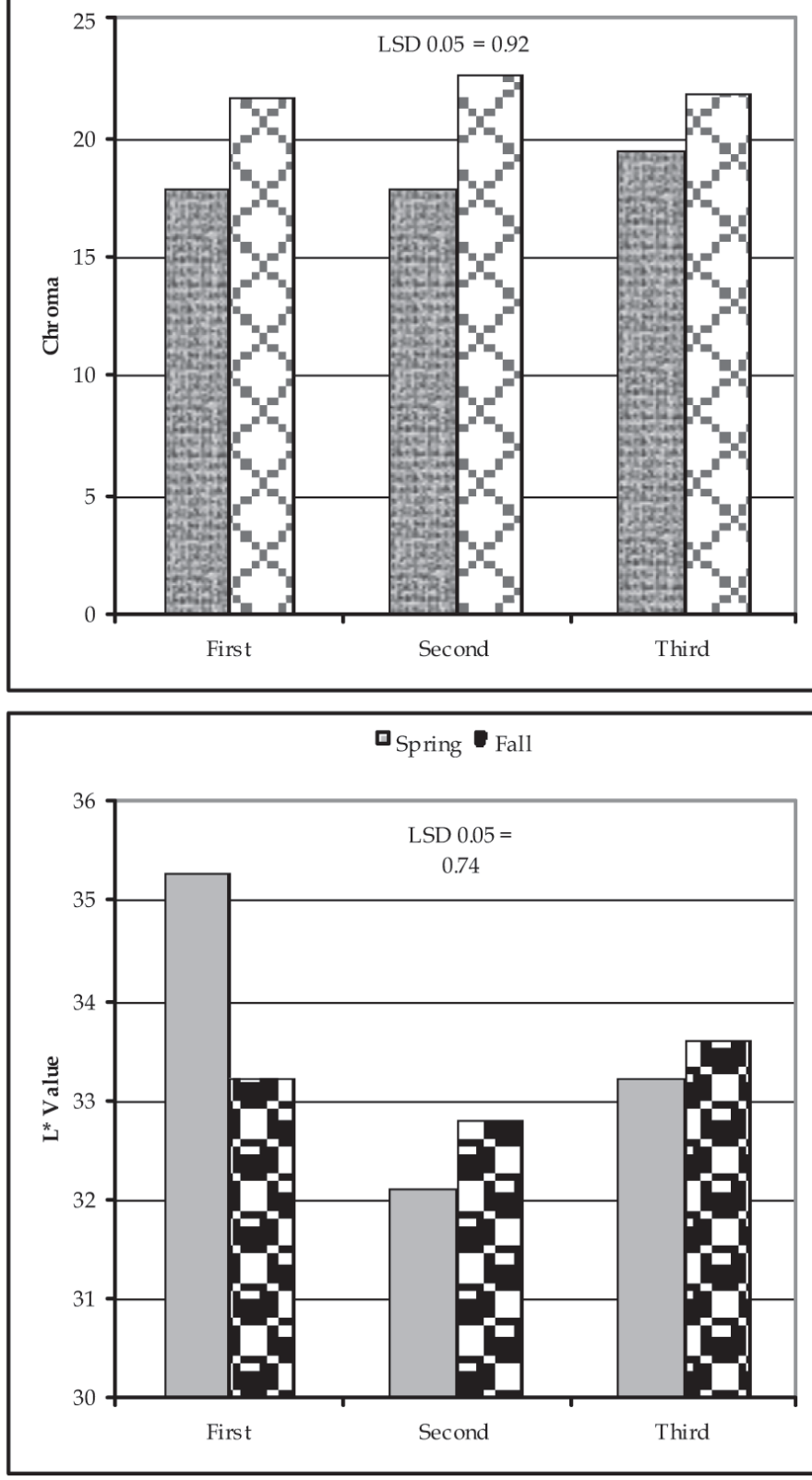
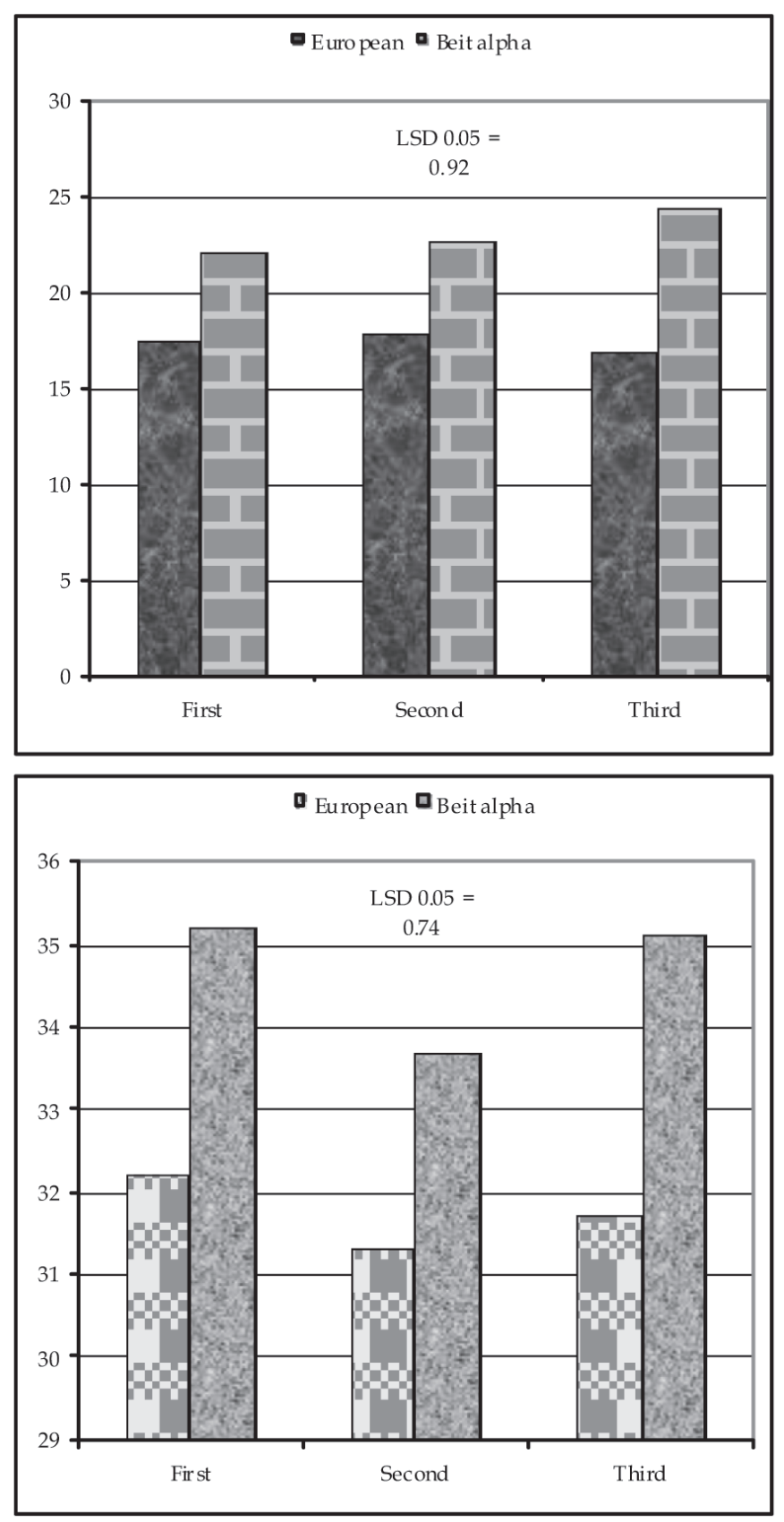

Fig. 5. Effects of interactions of sampling period with season and of sampling period with cucumber type for fruit chroma value and $L$ *value for cucumbers grown in perlite medium. Sampling periods were third, tenth, and fifteenth harvests. Higher chroma values are associated with greater perceived color. Smaller $L^{*}$ values are associated with darker color $\left(\mathrm{LSD}_{0.05}=\right.$ least significant difference at $P=0.05$ ).

intensity decreased with increased $\mathrm{N}$ fertilization. In the fall season, chroma value was lower (less intense color) with intermediate $\mathrm{N}$ concentrations for the European cucumber and decreased linearly with $\mathrm{N}$ concentration for the Beit-alpha cucumber.

\section{Conclusions}

Early fruit yield of European and Beit-alpha cucumbers, grown in a greenhouse, increased with N concentration, but total-season fruit yield was maximized with 225 to $250 \mathrm{mg} \cdot \mathrm{L}^{-1} \mathrm{~N}$ in the solution. Average seasonal fruit diameter and length were not affected by $\mathrm{N}$ concentration. Fruit firmness decreased with increasing $\mathrm{N}$ concentration. European cucumber fruits harvested later in fall and spring seasons were greener with increased fertilizer$\mathrm{N}$ concentration, but not early in the season. Greener fruits are more desirable in the commercial trade. Beit-alpha fruits were greener with increased $\mathrm{N}$ concentration throughout the spring season, but only later in the fall season. Fruits were darker with intermediate and higher solution $\mathrm{N}$ concentrations. Perceived color intensity decreased with higher $\mathrm{N}$ concentrations for both cultivars in the spring season and for the Beit-alpha type in the fall season. Color was most intense with intermediate $\mathrm{N}$ concentration for the European and Beit-alpha cucumbers in the fall season. Hue angle of $120^{\circ}$ to $130^{\circ}, \mathrm{L}^{*}$ value of 30 to 35 , and chroma value of 15 to 25 , were associated with marketable 
Table 4. Interaction effects of season, cucumber type, and nitrogen $(\mathrm{N})$ concentration on color darkness $\left(L^{*}\right.$ value) for cucumber fruit external color.

\begin{tabular}{|c|c|c|c|c|c|c|c|}
\hline \multirow[b]{2}{*}{ Season } & \multirow{2}{*}{$\begin{array}{c}\text { Cucumber } \\
\text { type }\end{array}$} & \multicolumn{5}{|c|}{$\begin{array}{c}\mathrm{L}^{*} \text { value }^{\mathrm{y}} \\
\text { Solution } \mathrm{N} \text { concn }\left[\mathrm{mg} \cdot \mathrm{L}^{-1}(\mathrm{ppm})\right]\end{array}$} & \multirow{2}{*}{$\begin{array}{c}\text { Model }^{\mathrm{z}} \\
\mathrm{Y}=\end{array}$} \\
\hline & & 75 & 150 & 225 & 300 & 375 & \\
\hline \multirow[t]{2}{*}{ Spring } & European & 32.6 & 31.9 & 31.9 & 32.4 & 31.4 & NS \\
\hline & Beit-alpha & 35.7 & 34.2 & 34.4 & 35.2 & 35.5 & $\begin{array}{l}36.8-0.02 \mathrm{~N} \\
+0.00005 \mathrm{~N}^{2}\end{array}$ \\
\hline \multirow[t]{2}{*}{ Fall } & European & 32.9 & 31.4 & 31.4 & 31.4 & 33.3 & $\begin{array}{l}35.1-0.037 \mathrm{~N} \\
+0.00008 \mathrm{~N}^{2}\end{array}$ \\
\hline & Beit-alpha & 36.8 & 34.9 & 33.9 & 33.6 & 32.3 & $37.4-0.014 \mathrm{~N}$ \\
\hline
\end{tabular}

${ }^{\mathrm{z}} \mathrm{N}$ is solution nitrogen concentration in $\mathrm{mg} \cdot \mathrm{L}^{-1}$

${ }^{y}$ Smaller $\mathrm{L}$ values are associated with darker color, where $0=$ black and $100=$ white.

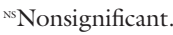

Table 5. Interaction effects of season, cucumber type, and nitrogen ( $N$ ) concentration on perceived color intensity (chroma value) for external cucumber fruit color.

\begin{tabular}{|c|c|c|c|c|c|c|c|}
\hline \multirow[b]{2}{*}{ Season } & \multirow{2}{*}{$\begin{array}{c}\text { Cucumber } \\
\text { type }\end{array}$} & \multicolumn{5}{|c|}{$\begin{array}{c}\text { Chroma value }{ }^{\mathrm{y}} \\
\text { Solution } \mathrm{N} \text { concn }\left[\mathrm{mg} \cdot \mathrm{L}^{-1}(\mathrm{ppm})\right]\end{array}$} & \multirow{2}{*}{$\begin{array}{c}\text { Model }^{\mathrm{z}} \\
\mathrm{Y}=\end{array}$} \\
\hline & & 75 & 150 & 225 & 300 & 375 & \\
\hline \multirow[t]{2}{*}{ Spring } & European & 16.4 & 16.8 & 15.1 & 15.1 & 14.6 & $17.3-0.0072 \mathrm{~N}$ \\
\hline & Beit-alpha & 22.3 & 21.7 & 20.6 & 21.0 & 19.7 & $22.8-0.0077 \mathrm{~N}$ \\
\hline \multirow[t]{2}{*}{ Fall } & European & 21.3 & 18.7 & 18.1 & 17.5 & 20.1 & $\begin{array}{l}25.4-0.064 \mathrm{~N} \\
+0.00013 \mathrm{~N}^{2}\end{array}$ \\
\hline & Beit-alpha & 27.8 & 26.6 & 24.7 & 24.3 & 21.7 & $29.3-0.019 \mathrm{~N}$ \\
\hline
\end{tabular}

${ }^{2} \mathrm{~N}$ is solution nitrogen concentration in $\mathrm{mg} \cdot \mathrm{L}^{-1}$

yigher chroma values are associated with greater perceived color intensity.

cucumber fruits. Considering factors of fruit yield, firmness, and fruit color quality, European and Beit-alpha cucumbers growing in perlite in warm climates should be irrigated frequently (up to 10 times daily, with $15 \%$ to $20 \%$ leach fraction, in our study) with a nutrient solution containing $\mathrm{N}$ at 225 to $250 \mathrm{mg} \cdot \mathrm{L}^{-1}$. This $\mathrm{N}$ concentration represented a good compromise for maximizing fruit color characteristics, fruit firmness, and fruit yield.

\section{Literature cited}

Castilla, N., F. Bretones, and J. LopezGalvez. 1991. Cucumber growth and yield in an unheated plastic greenhouse. Agricoltura Mediterranea 121:166-172.

Francis, F.J. 1970. Color measurement in plant breeding. HortScience 5:202-206.

Francis, F.J. 1980. Color quality evaluation of horticultural crops. HortScience 15:58-59.

Hochmuth, G.J. 2001. Fertilizer management for greenhouse vegetables. In: G.J. Hochmuth and R.C. Hochmuth (eds.). Florida greenhouse vegetable production handbook. Vol. 3. Fla. Coop. Ext. Serv. Fact Sheet HS787. 5 May 2004. <http://edishttp://edis.ifas.ufl.edu/CV265>.

Hochmuth, R.C. 2001. Greenhouse cu- cumber production. In: G.J. Hochmuth and R.C. Hochmuth (eds.). Florida greenhouse vegetable production handbook. Vol 3. Fla. Coop. Ext. Serv. Fact Sheet HS790. 5 May 2004. <http://edis.ifas. ufl.edu/CV268>.

Hochmuth, G.J. and R.C. Hochmuth. 2001. Nutrient solution formulation for hydroponic (perlite, rockwool, and NFT) tomatoes in Florida. Fla. Coop. Ext. Serv., Fact Sheet HS796. 5 May 2004. <http:// edis.ifas.ufl.edu/CV216>.

Hochmuth, G.J. and R.C. Hochmuth. 2003. Keys to successful tomato and $\mathrm{cu}^{-}$ cumber production in perlite media. Fla. Coop. Ext. Serv. 5 May 2004. <http://edis. ifas.ufl.edu/HS169>.

Hochmuth, R.C., L.C. Leon, and G.J. Hochmuth. 1996. Evaluation of twelve greenhouse cucumber cultivars and two training systems over two seasons in Florida. Proc. Fla. State Hort. Soc. 109:174-177.

Jones, J.B. 1983. A guide for the hydroponic soilless culture grower. Timber Press, Portland, Ore.

Jones, J.B., B. Wolf, and H.A. Mills. 1991. Plant analysis handbook. Micro-Macro Publ., Athens, Ga.

Locascio, S.J., W.J. Wiltbank, D.D. Gull, and D.N. Maynard. 1984. Fruit and vegetable quality as affected by nitrogen nutrition, p. 617-626. In: R.D. Hauck (ed.). Nitrogen in crop production. Amer. Soc. Agron., Madison, Wis.

Miner, G.S., E.B. Poling, D.E. Carroll, L.A. Nelson, and C.R. Campbell. 1997. Influence of fall nitrogen and spring nitrogen-potassium application on yield and fruit quality of 'Chandler' strawberry. J. Amer. Soc. Hort. Sci. 122:290-295.

Mozafar, A. 1993. Nitrogen fertilizers and the amount of vitamins in plants: A review. J. Plant Nutr. 16:2479-2506.

Papadopoulos, I. 1987. Nitrogen fertigation of greenhouse-grown tomato. Commun. Soil Sci. Plant Anal. 18:897-907.

Ruiz, J.M. and L. Romero. 1998. Commercial yield and quality of fruits of cucumber plants cultivated under greenhouse conditions: Response to increases in nitrogen fertilization. J. Agr. Food Chem. 46:4171-4173.

SAS Institute. 1993. SAS/STAT user's guide, release 6.03. SAS Inst., Cary, N.C.

Schon, M.K. and M.P. Compton. 1997a. Nitrogen and phosphorus requirements for rockwool-grown cucumbers trained with a double-stem method. HortTechnology 7:33-35.

Schon, M.K. and M.P. Compton. 1997b. Comparisons of cucumbers grown in rockwool or perlite at two leaching fractions. HortTechnology 7:30-33.

Sistrunk, W.A. and J.R. Morris. 1985. Strawberry quality: Influence of cultural and environmental factors, p. 217-256. In: H.E. Pattee (ed.). Evaluation of quality of fruits and vegetables. AVI Publ., Westport, Conn.

Smajstrla, A.G., D.S. Harrison, and F.S. Zazueta. 1988. Field evaluation of trickle irrigation systems: Uniformity of water application. Fla. Coop. Ext. Serv. Bul. 195.

Sweat, M.S. and G.J. Hochmuth. 2001. Production systems. In: G.J. Hochmuth and R.C. Hochmuth (eds.). Florida greenhouse vegetable production handbook. Vol. 3. Fla. Coop. Ext. Serv. 5 May 2004. <http://edis.ifas.ufl.edu/CV263>.

Tyson, R.V., R.C. Hochmuth, E.M. Lamb, G J. Hochmuth, and M.S. Sweat. 2001. A decade of change in Florida's greenhouse vegetable industry: 1991-2001. Proc. Fla. State Hort. Soc. 114:280-283.

U.S. Dept. of Agriculture 1997. United States standards for grades of greenhouse cucumbers. U.S. Dept. Agr. Mktg. Serv., Washington, D.C.

Villalta, A.M., S.A. Sargent, A.D. Berry, and D.J. Huber. 2003. Sensitivity of Beit alpha cucumber (Cucumis sativus L.) to low temperature storage. Proc. Fla. State Hort. Soc. 116:364-366. 